\title{
The new economic governance of the Eurozone
}

Citation for published version (APA):

Dermine, P. (2020). The new economic governance of the Eurozone: A rule of law analysis. [Doctoral

Thesis, Maastricht University, KU Leuven]. Maastricht University. https://doi.org/10.26481/dis.20201022pd

Document status and date:

Published: 01/01/2020

DOI:

10.26481/dis.20201022pd

Document Version:

Publisher's PDF, also known as Version of record

\section{Please check the document version of this publication:}

- A submitted manuscript is the version of the article upon submission and before peer-review. There can be important differences between the submitted version and the official published version of record.

People interested in the research are advised to contact the author for the final version of the publication, or visit the DOI to the publisher's website.

- The final author version and the galley proof are versions of the publication after peer review.

- The final published version features the final layout of the paper including the volume, issue and page numbers.

Link to publication

\footnotetext{
General rights rights.

- You may freely distribute the URL identifying the publication in the public portal. please follow below link for the End User Agreement:

www.umlib.nl/taverne-license

Take down policy

If you believe that this document breaches copyright please contact us at:

repository@maastrichtuniversity.nl

providing details and we will investigate your claim.
}

Copyright and moral rights for the publications made accessible in the public portal are retained by the authors and/or other copyright owners and it is a condition of accessing publications that users recognise and abide by the legal requirements associated with these

- Users may download and print one copy of any publication from the public portal for the purpose of private study or research.

- You may not further distribute the material or use it for any profit-making activity or commercial gain

If the publication is distributed under the terms of Article $25 \mathrm{fa}$ of the Dutch Copyright Act, indicated by the "Taverne" license above, 


\section{Summary}

The Eurozone crisis has radically reshaped the inner structures of the Economic and Monetary Union (EMU). The economic pillar of the construct, in particular, has undergone an unprecedented metamorphosis. Reforms such as the Treaty on Stability, Coordination and Governance (TSCG), the Six-Pack, or the Two-Pack have brought about a new regime of economic governance in the Eurozone and have dramatically changed the ways economic, fiscal and social policies are being conducted in the currency union. These changes, which constitute the object of this doctoral research, beg many questions of a constitutional nature, as to the power relationships between the European Union (EU) and the Member States in the Eurozone, the institutional equilibria at the supranational level, the ability of law to constrain political and economic power, or the place of the individual in the integration project. The main ambition of this research has been to determine if, and to what extent, the new economic governance of the Eurozone adheres to the founding constitutional guarantees of the EU legal order, namely those drawn from the rule of law principle. In so doing, it has answered the following research question: in its post-crisis version, does the economic and budgetary governance framework of the Eurozone live up to the EU's constitutional commitment to the rule of law? In order to do so, this doctoral thesis has proceeded in a three-step process.

Part I elaborated on the analytical framework on which the thesis relied to conduct its assessment of post-crisis economic governance in the Eurozone. It came clear with the understanding of the rule of law it favored: a teleological approach (informed by the main purposes pursued by the concept, namely the prevention of arbitrariness and the generation of trust), adjusted to the specific context of the EU (the 'EU rule of law'). From there, four 'rule of law' benchmarks were identified: compliance with vertical separation of powers and the competence allocation system of the Treaties; internal quality of substantive rules; the availability of external review; and the sustainability of fundamental rights.

Part II provided a clear understanding of the new economic governance of the Eurozone. Chapter 1 offered an in-depth overview of the many substantive, procedural and institutional changes introduced by the various reforms adopted in the field of economic policy in the aftermath of the crisis. Chapter 2 made sense of these changes from a governance perspective. It showed how the Eurocrisis brought about a new type of EU intervention in the field of economic policy, based on a vertical, substantive and harmonizing type of policy coordination.

Part III assessed the new economic governance of the Eurozone in the light of the 'rule of law' framework previously elaborated.

Chapter 1 appraised the new economic governance of the Eurozone in the light of the competence allocation system of the Union and its underlying principle of conferral. It found that the advent of a new economic governance framework in the Eurozone was not irreconcilable with that system, but rather materialized the spirit of purposive openness and contextual adaptability of the Treaty provisions on economic policy. It also warned that the EU legislator had reached the outer edge of what is constitutionally feasible and that any further consolidation of the economic pillar would require Treaty revision.

Chapter 2 conducted a qualitative assessment of the main policy rules underlying the new economic governance of the Eurozone. It found that they suffer from serious qualitative flaws, pertaining to their complexity, their opacity, their internal inconsistency, and the unconstrained 
discretion that the Commission enjoys as their main enforcer. It argued that the system's reliance on policy rules had become excessive and counter-productive, as it now works against the objectives of certainty and stability that it was supposed to achieve, instills distrust and facilitates arbitrariness. Hence, it highlighted the pressing need for an overhaul of the existing policy rules and a deeper institutional reflection about the legitimacy of the rules-based approach to economic and fiscal governance.

Chapter 3 investigated the availability of external review under the new economic governance of the Eurozone. It showed that, so far, the transformation of the EU's powers in the economic and fiscal fields did not come together with a parallel intensification of judicial scrutiny by the Court of Justice. It also found that, considering the Court's current case law and the conceptual frameworks that continue to structure its action, a shift in approach is quite unlikely. The result is a profound disconnect between the evolving nature of law and governance in the realm of EU economic policy and its judicial apprehension by the Court of Justice, an inappropriate level of review and a widening accountability gap. Chapter 3 noted that several bodies (such as the Court of Auditors or the European Fiscal Board) sought to instill a certain dose of review, without compensating the lack of judicial review however. Chapter 3 finally enjoined the Court to lift the constitutional uncertainty produced by the new economic governance of the Eurozone, to come to terms with what standard economic governance has progressively become and to make sure that supranational judicial scrutiny keeps up with the evolving powers of the EU.

Finally, Chapter 4 analyzed the question of fundamental rights sustainability under economic governance in the post-crisis era. In this Chapter, the core finding was that of a fundamental discrepancy between the evolution of post-crisis economic governance towards a more constraining and supra-nationally driven system of harmonization and the institutional position of fundamental rights. Under the current configuration, that system's ability to impact levels of rights protection in a systemic manner is not matched with equivalent safeguards. In spite of its clear applicability and multiple references in the relevant legislation, the body of EU fundamental rights only plays a peripheral role in the various policy-making processes making up standard economic governance. Rights mainstreaming is close to non-existent, and the Charter does not guide or constrain policy deliberation in any meaningful way. Moreover, there is no sign that external reviewers (either the Court of Justice or the Fundamental Rights Agency) are ready to redress these deficiencies.

Overall, it flows from these findings that the transformation of Eurozone economic governance in the aftermath of the Eurocrisis, and its shift from one coordination model to another, has not been accompanied by a parallel and consonant adjustment of its 'rule of law' settlement. For each one of the analytical criteria, I noted certain evolutions, but of a clearly insufficient magnitude to found the new economic governance of the Eurozone on the solid constitutional guarantees it needs. On the contrary, it was observed that, whereas economic and fiscal governance decidedly moved away from the pre-crisis pattern of coordination, the constitutional settlement on which that pre-crisis model relied has been perpetuated without any meaningful redefinition nor any upgrade of its 'rule of law' credentials. As a result, the crisis and its aftermath have brought about significant discrepancies, opened wide 'rule of law' gaps and has led to a paradoxical misalignment between what economic governance has become today and its constitutional foundations. The new economic governance of the Eurozone thus fails to live up to the Union's constitutional commitment to the rule of law. 